\title{
Improvements in Drill-Core Headspace Gas Analysis for Samples from Microbially Active Depths
}

\author{
Kazuya Miyakawa $\mathbb{D}^{1}$ and Fumiaki Okumura ${ }^{2}$ \\ ${ }^{1}$ Horonobe Underground Research Center, Japan Atomic Energy Agency, Hokushin 432-2, Horonobe-cho, Hokkaido 098-3224, Japan \\ ${ }^{2}$ JAPEX Research Center, Japan Petroleum Exploration Co., Ltd., 1-2-1 Hamada, Mihama-ku, Chiba 261-0025, Japan \\ Correspondence should be addressed to Kazuya Miyakawa; miyakawa.kazuya@d.nagoya-u.jp
}

Received 11 April 2018; Accepted 29 July 2018; Published 1 October 2018

Academic Editor: Andri Stefansson

Copyright (C) 2018 Kazuya Miyakawa and Fumiaki Okumura. This is an open access article distributed under the Creative Commons Attribution License, which permits unrestricted use, distribution, and reproduction in any medium, provided the original work is properly cited.

\begin{abstract}
The IsoJar ${ }^{\mathrm{TM}}$ container is widely used in headspace gas analysis for gases adsorbed on cuttings or bore cores from oil and gas fields. However, large variations in the carbon isotopic ratios of $\mathrm{CH}_{4}$ and $\mathrm{CO}_{2}$ are often reported, especially for data obtained from depths of $<1000 \mathrm{~m}$. The IsoJar ${ }^{\mathrm{TM}}$ method leaves air in the headspace that allows microbial oxidation of $\mathrm{CH}_{4}$ to $\mathrm{CO}_{2}$, meaning that isotopic fractionation occurs during storage. This study employed the IsoJar ${ }^{\mathrm{TM}}$ method to investigate the causes of differences in $\delta^{13} \mathrm{C}$ data reported by previous studies in the Horonobe area of Japan. It was found that after $80 \mathrm{~d}$ storage, $\delta^{13} \mathrm{C}_{\mathrm{CO} 2}$ values decreased by $\sim 2 \%$, while $\delta^{13} \mathrm{C}_{\mathrm{CH} 4}$ values increased by $>30 \%$, whereas samples analyzed within a week of collection showed no such fluctuations. The conventional amount of microbial suppressant $(\sim 0.5 \mathrm{ml}$ of $10 \%$ benzalkonium chloride (BKC) solution) is insufficient to suppress microbial activity if groundwater is used as filling water. The significant variations in carbon isotopic compositions previously reported were caused by microbial methane oxidation after sampling and contamination by groundwater from different depths. To avoid these problems, we recommend the following: (1) if long-term sample storage is necessary, $>10 \mathrm{ml}$ of $10 \%$ BKC solution should be added or $>0.3 \%$ BKC concentration is required to suppress microbial activity; (2) analyses should be performed within one week of sampling; and (3) for $\mathrm{CO}_{2}$ analyses, it is important that samples are not contaminated by groundwater from different depths.
\end{abstract}

\section{Introduction}

Investigation of the origin of deep hydrocarbons is an important aspect of resource exploration and may lead to an improved understanding of geological environments. In this investigation, gases adsorbed on rock fragments or bore cores were studied by headspace gas analysis (e.g., [1-5]), which provides information on the generation and migration of light hydrocarbons and gases. The IsoJar ${ }^{\mathrm{TM}}$ (Isotech Laboratories and Humble Instruments, USA) container, which is widely used in such analyses (e.g., $[6,7])$ comprises a plastic container of $\sim 600 \mathrm{ml}$ volume with an aluminum screw cap on which there is a rubber septum through which headspace gas can be taken by syringe. The analysis procedure (e.g., [8]) normally involves storage of wet cuttings or cores in the jar with water and an air headspace for several days or weeks, the addition of a microbicide such as benzalkonium chloride
(BKC) to minimize bacterial activity, the partitioning of gas into the headspace during storage, and analysis of these gases (e.g., [9-11]). The use of distilled or tap water avoids contamination from dissolved gases. The $\delta^{13} \mathrm{C}_{\mathrm{CH} 4}$ values of gases from depths of $<1000 \mathrm{~m}$, in the biogenic region, are usually in the range of $-70 \%$ o to $-60 \%$, with isotopic compositions becoming heavier as depth increases towards the thermogenic region (e.g., $[12,13])$. Large variations in carbon isotopic ratios in $\mathrm{CH}_{4}$ and $\mathrm{CO}_{2}$ are often reported for depths of $<1000 \mathrm{~m}$, with $\delta^{13} \mathrm{C}_{\mathrm{CH} 4}$ values sometimes reaching $-20 \%$ o (e.g., [14-17]). These variations are associated with the effects of microbial activity on methane production or oxidation in underground environments [18]. There are a number of factors that control the rate of methanogenesis [19], including temperature [20], groundwater salinity [21], $\mathrm{pH}$ [22], and pore space [23]. Peak microbial activity occurs at $35-45^{\circ} \mathrm{C}$, which corresponds to depths of $<1000 \mathrm{~m}[19,24]$. 
At greater depths, microbial action decreases as thermogenic production increases with the onset of catagenesis (subsequent to diagenesis at shallower depths [8]). More importantly, pore diameters of at least $1 \mu \mathrm{m}$ are necessary for in situ methanogenesis, as microbes are in the $1-10 \mu \mathrm{m}$ size range [25], which suggests that active methane production occurs at depths of $<1500 \mathrm{~m}$ [24]. At shallow depths (less than several meters) below the ocean floor, where the concentration of dissolved gas is relatively low, considerable care was taken to avoid contamination and microbial activity (e.g., [26]). Hachikubo et al. [27] adjusted the concentration of BKC in samples to $2.5 \%$ using $25 \mathrm{ml}$ vials to obtain precise depth profiles of gases relative to hydrates. While the concentration and/or amount of microbicide normally added to IsoJar ${ }^{\mathrm{TM}}$ vessels are often omitted in reports, it is considered that the final concentration in IsoJar ${ }^{\mathrm{TM}}$ containers should be of the order of $0.01 \%$, which is two orders of magnitude less than that reported by Hachikubo et al. [27]. It is speculated that another possible cause of variations in carbon isotopic composition may be microbial activity in the headspace after sampling, as the amount of microbicide commonly used with samples from microbially active depths might be insufficient to suppress microbial activity.

In a previous study, gas samples from two boreholes (PB-V01 and SAB-1, both $\sim 500 \mathrm{~m}$ deep) in the Horonobe area, Hokkaido, were processed using IsoJar ${ }^{\mathrm{TM}}$ containers [14]. In that study, cores were stored in IsoJar ${ }^{\mathrm{TM}}$ containers with water and a few drops of BKC solution [14] for up to three months before headspace analysis. Because sampling date of cores and analysis date of gases, which are necessary for the calculation of the storage period, have not been presented in Funaki et al. [14], these unpublished information are summarized in Tables S1a and S1b. Concentration of the BKC solution and amounts of cores and water also have not been reported in Funaki et al. [14]. In the conventional way of using IsoJar ${ }^{\mathrm{TM}}$ headspace gas analysis, it is considered that the concentration of BKC solution is lower than $10 \%$, in which case concentrations of BKC in jars are in order of $0.01 \%$. In the construction of the Horonobe Underground Research Laboratory (URL), including two boreholes (PBV01 and SAB-1), water was collected from groundwater at $\sim 50 \mathrm{~m}$ depth, and this was used by Funaki et al. [14] as filling water for the IsoJar ${ }^{\mathrm{TM}}$ containers. Gases dissolved in deep groundwater from the URL were also analyzed, using an evacuated-vial (EV) method [28]. Measured $\delta^{13} \mathrm{C}$ values for $\mathrm{CH}_{4}$ and $\mathrm{CO}_{2}$ from both sets of analyses are plotted against each other in Figure 1. Large variations in $\delta^{13} \mathrm{C}_{\mathrm{CH} 4}$ values from the IsoJar ${ }^{\mathrm{TM}}$ measurements (Figure 1) were attributed to methane-oxidizing bacterial activity using sulfate ions in the deep underground environment or to isotopic fractionation during gas migration through fractures [14]. However, these possible causes are considered unlikely because (a) geochemical studies in the Horonobe area indicate that reducing conditions are maintained deep underground and sulfate ions are either absent or present at very low concentrations [29-32]; (b) studies of iodine enrichment [33] indicates that any traces of methane oxidation by sulfate in pore waters of sediments would have been erased during upward fluid flow due to compaction during burial; and

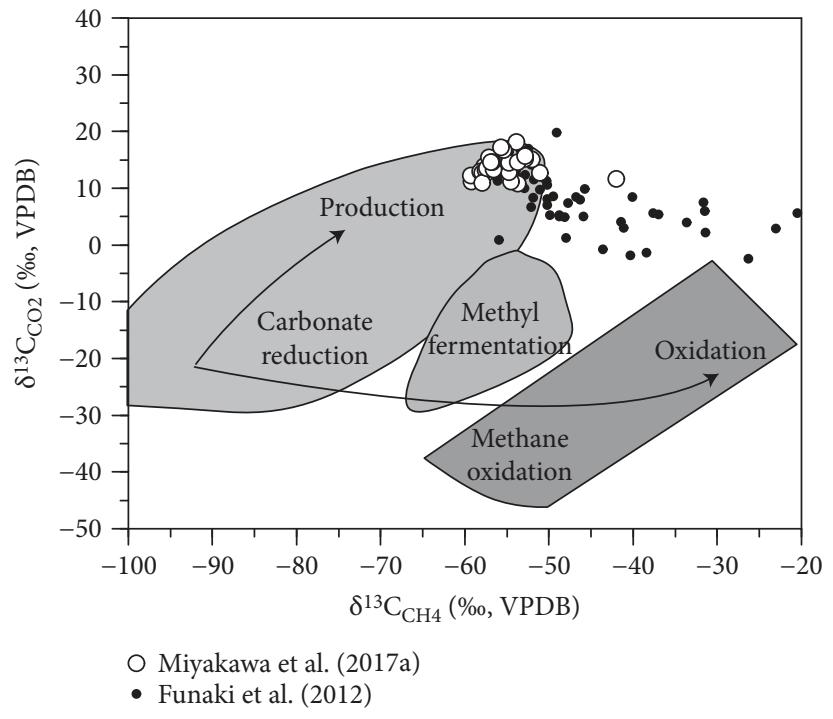

Figure 1: Plot of $\delta^{13} \mathrm{C}_{\mathrm{CH} 4}$ vs. $\delta^{13} \mathrm{C}_{\mathrm{CO} 2}$ in coexisting gases, showing fields relating to different gas sources and isotopic shifts resulting from production and oxidation (adapted from [50]). The data are from Funaki et al. [14] and Miyakawa et al. [28].

(c) there is no evidence in the study area of isotopic fractionation in gases during migration $[34,35]$. The $\delta^{13} \mathrm{C}_{\mathrm{CH} 4}$ and $\delta^{13} \mathrm{C}_{\mathrm{CO} 2}$ values obtained by the $\mathrm{EV}$ method (Figure 1) show little scatter plotting in the carbonate reduction field.

Differences between these data sets could be attributed to factors such as aerobic microbial oxidation of methane in the containers after sampling and/or using groundwater from the different depths of core samples. Possible causes were investigated in the present study to improve the methodology of headspace gas analysis using IsoJar ${ }^{\mathrm{TM}}$. Gases from the Wakkanai Formation in the Horonobe area were sampled using the methods of Funaki et al. [14] and Miyakawa et al. [28]. The effects of the sampling method (storage period, water type, and additives) on carbon isotopic ratios in $\mathrm{CH}_{4}$ and $\mathrm{CO}_{2}$ were investigated, and improvements in headspace gas analysis techniques are suggested.

\section{Geological Setting}

The Horonobe area is located in northwestern Hokkaido, in a Neogene-Quaternary sedimentary basin (Figure 2). Since August 2006, the Japan Atomic Energy Agency (JAEA) has been excavating the URL for a research associated with the development of technologies related to the geological disposal of high-level radioactive waste. Geologically, the URL area comprises marine sediments of the Wakkanai Formation (Neogene siliceous mudstone containing opal-CT) and Koetoi Formation (Neogene-Quaternary diatomaceous mudstone containing opal-A). Burial and subsidence of these formations occurred throughout the Neogene and Quaternary, when they underwent early diagenetic thermal alteration at temperatures of $\angle 60^{\circ} \mathrm{C}$ [36]. The URL and surrounding geology are depicted in Figure 3. The highpressure boreholes have steel casings, with valves allowing the sampling of groundwater from multiple depths or zones 
(a)

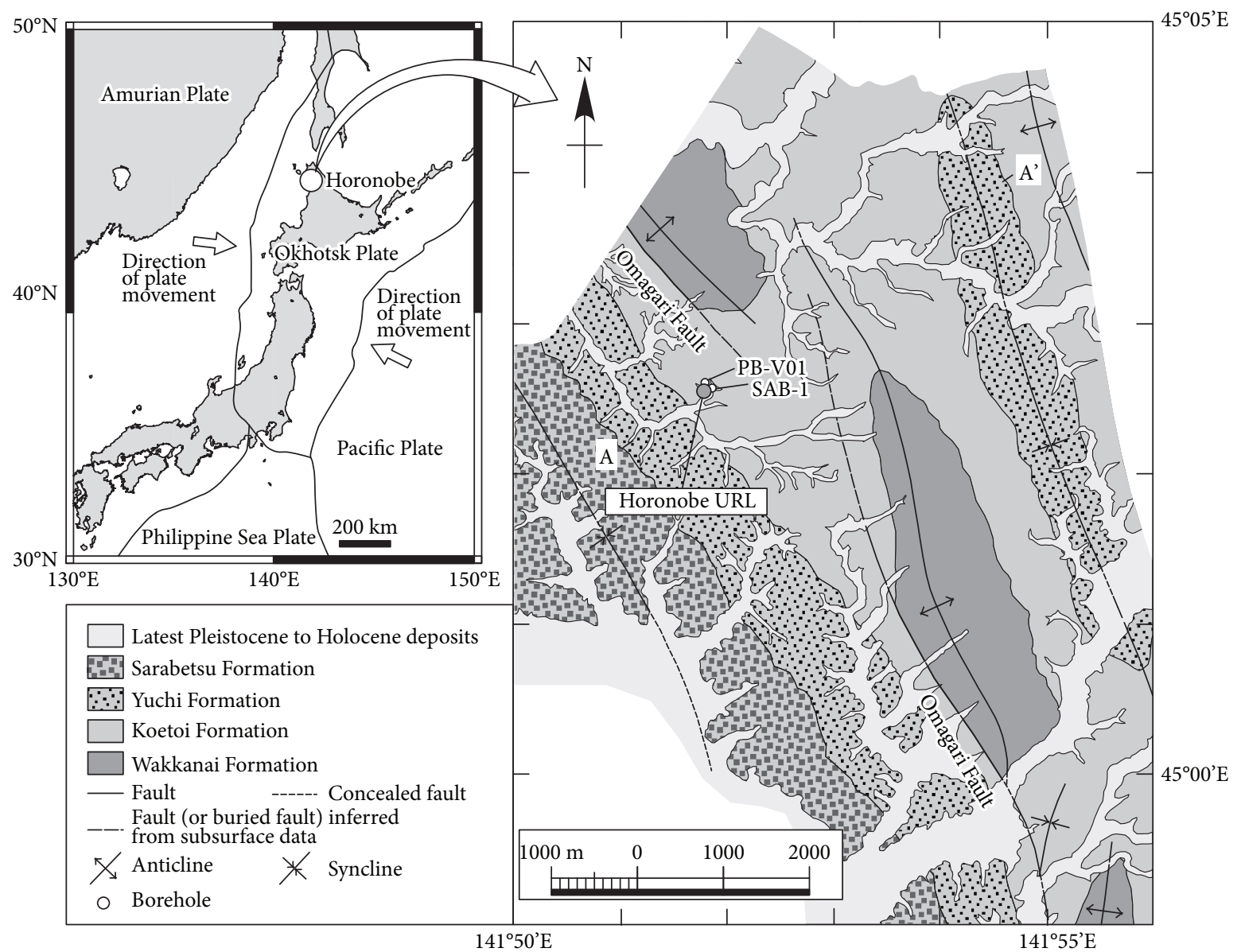

FIgURE 2: Maps showing the location of the Horonobe URL site and the boreholes: (a) location map and (b) geological map (after [51]). The plate boundaries and the direction of plate movement in (a) are from Wei and Seno [52].

[37]. The $\delta \mathrm{D}$ vs. $\delta^{18} \mathrm{O}$ plots for groundwater from the Wakkanai and Koetoi Formations indicate that it is a mixture of local meteoric water and altered seawater [38, 39]. Methanogenic and methane-oxidizing microbial communities have played an important role in these formations [40-42], where secondary microbial gas with ${ }^{13} \mathrm{C}$-enriched isotopic values $\left(\delta^{13} \mathrm{C}_{\mathrm{CH} 4},-74 \%\right.$ o to $-28 \%$; $\delta^{13} \mathrm{C}_{\mathrm{CO} 2},-7 \%$ o to $+31 \%$ ) formed through $\mathrm{CO}_{2}$ reduction after uplift of the area [28].

\section{Sampling and Analytical Methods}

\subsection{IsoJar ${ }^{\mathrm{TM}}$ Samples}

3.1.1. Effect of Storage Period. Core samples including in situ pore water (300-400 g), crushed to pieces roughly $30-50 \mathrm{~mm}$ in diameter, were placed in IsoJar ${ }^{\mathrm{TM}}$ containers with 250$300 \mathrm{~g}$ of "filling" water. $\mathrm{HgCl}_{2}$-saturated or $10 \% \mathrm{BKC}$ aqueous solution (10 drops $(\sim 0.5 \mathrm{ml})$ of either) was added to suppress microbial activity, and the jars were sealed with an air headspace. Final concentrations of both microbicides in the jars were about $0.01 \%-0.02 \%$. The jars were kept in the dark at room temperature for 5-92 d before analysis. Details of each experiment are summarized in Table 1 and Table S2.
The cores were obtained immediately after drilling of borehole 350-Fz-01 from the bottom of the east shaft (Figure 3). Although distilled or tap water is usually used in the IsoJar ${ }^{\mathrm{TM}}$ method, groundwater from depths of 53.5$64.5 \mathrm{~m}$ and $350 \mathrm{~m}$ in borehole 13-350-C01 (drilled in the $350 \mathrm{~m}$ gallery; Figure 3 ) was used to match the $50 \mathrm{~m}$ groundwater used by Funaki et al. [14]. The priority in this study was to evaluate the effects of sampling method on the carbon isotopic ratios of $\mathrm{CH}_{4}$ and $\mathrm{CO}_{2}$, rather than to obtain accurate in situ values. A large portion of $\mathrm{CH}_{4}$ dissolved in groundwater around the URL had already escaped due to the pressure decrease associated with excavation, so it was expected that only small amounts of gas would remain in cores. Groundwater, rather than tap water, was used to compensate for this (with water from borehole 13-350-C01 being used because water was not available from borehole $350-\mathrm{Fz}-$ 01). Core samples IJ1-IJ25 were from depths of 384-416 m (Table S2). Core samples IJ26-IJ28 were from a depth of $470 \mathrm{~m}$ (Table S2) and kept in vacuum storage for one month after drilling. At these depths, the $\mathrm{C}$ isotopic ratios for $\mathrm{CH}_{4}$ and $\mathrm{CO}_{2}$ had similar values to those from $350 \mathrm{~m}$ depth [28].

3.1.2. Effect of Additives. The effective amount of additives was investigated as follows. IsoJar ${ }^{\mathrm{TM}}$ samples were prepared 


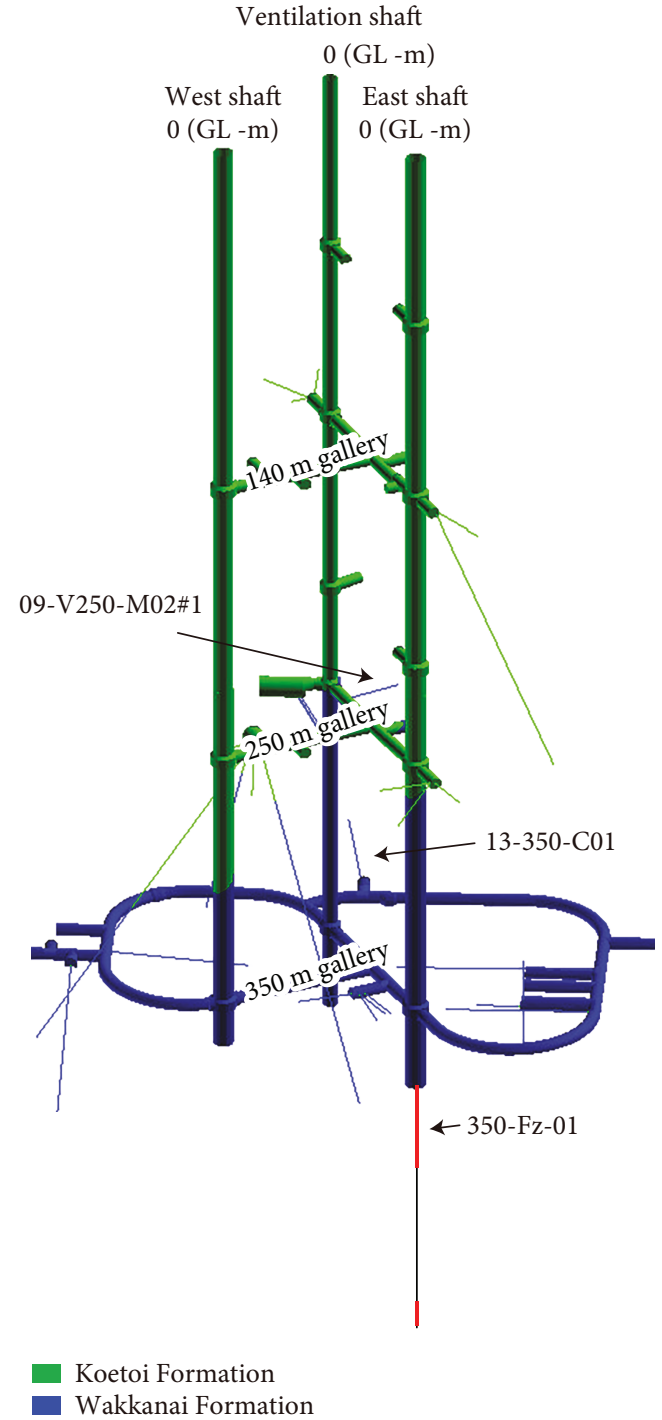

FIgURE 3: Layout of the Horonobe URL, locations of boreholes, and surrounding geology. Red color-labelled "borehole 350-Fz-01" indicates core sampling depths (Table S2).

as described in Section 3.1.1, with up to $20 \mathrm{ml}$ of BKC and $\mathrm{HgCl}_{2}$ solutions per jar (Table 2 and Table S3). All core samples were from a depth of $480 \mathrm{~m}$ in 350-Fz-01. Fresh cores taken immediately after drilling were not available for analysis, and the samples used in this study had been kept in vacuum storage for about six months. Groundwater from borehole 13-350-C01 was used as filling water. Headspace gas compositions were determined after storage in IsoJar ${ }^{\mathrm{TM}}$ for one month.

3.2. EV Samples. The EV sampling procedure involved the preliminary evacuation of septum-topped $50 \mathrm{ml}$ glass vials containing $\sim 1 \mathrm{ml}$ phosphoric acid (85 wt\%). Acidification removed any inorganic carbon as $\mathrm{CO}_{2}$, with the $\mathrm{CO}_{2}$ concentration being measured as total inorganic carbon (TIC). Groundwater (15-30 ml, from borehole 09-V250-M02\#1 drilled from the $250 \mathrm{~m}$ gallery; Figure 3) was introduced by a syringe through a $0.22 \mu \mathrm{m}$ membrane filter to remove microsized carbonate grains and microbes. Samples were stored in the dark at room temperature for 5-98d, after which ultrapure He was added by a syringe to equalize headspace gas and atmospheric pressures. The sample was left to stand overnight for gas exchange equilibrium to be established between the headspace and dissolved gases. The composition of the headspace gas was determined by GC, with the concentration of dissolved gas being calculated using Henry's law and the ideal gas equation.

3.3. Analytical Procedure. Gases adsorbed on rock fragments in the IsoJar ${ }^{\mathrm{TM}}$ containers were desorbed into the headspace by ultrasonic shaking. Concentrations of $\mathrm{O}_{2}, \mathrm{~N}_{2}, \mathrm{CO}_{2}, \mathrm{CH}_{4}$, $\mathrm{C}_{2} \mathrm{H}_{6}$, and $\mathrm{C}_{3} \mathrm{H}_{8}$ in headspace gas were determined by gas chromatography (GC) using a GC7890A Valve System (Agilent Technologies, USA). Carbon isotopic values $\left(\delta^{13} \mathrm{C}_{\mathrm{CH} 4}\right.$ and $\delta^{13} \mathrm{C}_{\mathrm{CO} 2}$ ) were determined by GC combustion isotoperatio mass spectrometry (GC-C-IRMS), using an IsoPrime GC-MS system (GV Instruments, UK), and are expressed in the usual VPDB $\delta$ notation. The lower limit of determination of carbon isotope ratios $\left(\delta^{13} \mathrm{C}_{\mathrm{CH} 4}\right.$ and $\left.\delta^{13} \mathrm{C}_{\mathrm{CO} 2}\right)$ requires concentrations of $0.01 \%$. Details of GC and GC-C-IRMS procedures can be found in Waseda and Iwano [43].

\section{Results}

Headspace concentrations of the gases analyzed and $\delta^{13} \mathrm{C}_{\mathrm{CH} 4}$ and $\delta^{13} \mathrm{C}_{\mathrm{CO} 2}$ values for the IsoJar ${ }^{\mathrm{TM}}$ samples prepared as described in Section 3.1.1 are listed in Table 1 and Table S2, and the results for the EV samples are listed in Table 3 and Table S4.

Sample contamination by air does not affect the present discussion of isotopic ratios because concentrations of $\mathrm{CH}_{4}$ and $\mathrm{CO}_{2}$ in air are much lower than those in the free gas from groundwater (where $\mathrm{CH}_{4}=74 \%-100 \% ; \mathrm{CO}_{2}=1 \%-$ $20 \%$; $[28,34])$.

$\mathrm{CO}_{2}$ in the free gas undergoes isotopic fractionation during exchange with dissolved inorganic carbon (e.g., $\mathrm{CO}_{2(\mathrm{aq})}$, $\mathrm{HCO}_{3}{ }^{-}$, and $\mathrm{CO}_{3}{ }^{2-}$ ), with $\mathrm{HCO}_{3}{ }^{-}$being the dominant aqueous species at around neutral $\mathrm{pH}$. To compare $\delta^{13} \mathrm{C}_{\mathrm{CO} 2}$ values of the IsoJar ${ }^{\mathrm{TM}}$ samples with those of the EV samples, a fractionation correction (intrinsic isotopic fractionation factor) of $+7.9 \%$ between $\mathrm{CO}_{2}$ gas and $\mathrm{HCO}_{3}{ }^{-}$at $25^{\circ} \mathrm{C}$ [44] was added to $\delta^{13} \mathrm{C}_{\mathrm{CO} 2}$ values measured for the IsoJar ${ }^{\mathrm{TM}}$ samples. The range of room temperatures was $20^{\circ} \mathrm{C}-25^{\circ} \mathrm{C}$, giving an error of up to $-0.6 \%$.

Variations in $\delta^{13} \mathrm{C}_{\mathrm{CO} 2}$ and $\delta^{13} \mathrm{C}_{\mathrm{CH} 4}$ values with storage time are shown in Figures 4(a) and 4(b), respectively. IsoJar ${ }^{\mathrm{TM}}$ samples with groundwater $(350 \mathrm{~m})$ stored for less than one week give values similar to the EV samples. Storage periods of $\leq 7 \mathrm{~d}$ and $\geq 20 \mathrm{~d}$ were considered, as no data are available for the interval of 7-20 d.

The $\delta^{13} \mathrm{C}_{\mathrm{CO} 2}$ and $\delta^{13} \mathrm{C}_{\mathrm{CH} 4}$ ratios for the EV samples are relatively constant, although $\delta^{13} \mathrm{C}_{\mathrm{CH} 4}$ values show a small variation $(<4 \%$ ) after $98 \mathrm{~d}$ (Figure $4(\mathrm{~b}))$, which is consistent with a previous study [28]. It is possible that some microbes are not removed by $0.22 \mu \mathrm{m}$ groundwater filtration (e.g., [45]), and this might have caused the slight variation in $\delta^{13} \mathrm{C}_{\mathrm{CH} 4}$ values. Differences between carbon isotopic values 
TABLE 1: Information on IsoJar ${ }^{\mathrm{TM}}$ samples and analytical results of headspace gases.

\begin{tabular}{|c|c|c|c|c|c|c|c|c|c|c|c|}
\hline $\begin{array}{l}\text { Sample } \\
\text { no. }\end{array}$ & $\begin{array}{c}\text { Amount of core } \\
\text { sample }(\mathrm{g})\end{array}$ & $\begin{array}{c}\text { Amount of } \\
\text { water }(\mathrm{g})\end{array}$ & $\begin{array}{c}\text { Depth of } \\
\text { groundwater }\end{array}$ & $\begin{array}{l}\text { Type of } \\
\text { additive }\end{array}$ & $\begin{array}{l}\text { Storage period } \\
\text { (days) }\end{array}$ & $\begin{array}{l}\mathrm{CO}_{2} \\
(\%)\end{array}$ & $\begin{array}{l}\mathrm{O}_{2} \\
(\%)\end{array}$ & $\begin{array}{l}\mathrm{N}_{2} \\
(\%)\end{array}$ & $\begin{array}{l}\mathrm{CH}_{4} \\
(\%)\end{array}$ & $\begin{array}{c}\delta^{13} \mathrm{C}_{\mathrm{CH} 4} \\
(\% \circ \mathrm{VPDB})\end{array}$ & $\begin{array}{c}\delta^{13} \mathrm{C}_{\mathrm{CO} 2} \\
(\% \circ \mathrm{VPDB})\end{array}$ \\
\hline IJ1 & 220 & 350 & $350 \mathrm{~m}$ & None & 67 & 6.5 & 6.9 & 83 & 0.030 & -45.4 & +13.6 \\
\hline IJ2 & 369 & 262 & $350 \mathrm{~m}$ & None & 41 & 8.9 & 2.8 & 79 & 6.7 & -35.5 & +13.2 \\
\hline IJ3 & 342 & 304 & $350 \mathrm{~m}$ & None & 79 & 3.1 & 11.0 & 80 & 2.8 & -30.8 & +13.2 \\
\hline IJ4 & 360 & 269 & $50 \mathrm{~m}$ & None & 17 & 0.63 & 14.6 & 80 & 2.2 & -49.3 & +5.0 \\
\hline IJ5 & 239 & 333 & $50 \mathrm{~m}$ & None & 68 & 2.3 & 9.4 & 86 & 0.014 & -51.4 & +2.1 \\
\hline IJ6 & 411 & 247 & $50 \mathrm{~m}$ & None & 42 & 6.7 & 0.01 & 79 & 12.5 & -42.5 & +3.5 \\
\hline IJ7 & 339 & 277 & $50 \mathrm{~m}$ & None & 79 & 2.5 & 5.4 & 80 & 9.6 & -36.8 & -1.0 \\
\hline IJ8 & 338 & 279 & $50 \mathrm{~m}$ & None & 79 & 0.36 & 18.1 & 79 & 0.45 & -22.3 & -1.4 \\
\hline IJ9 & 302 & 274 & $350 \mathrm{~m}$ & $\mathrm{HgCl}_{2}$ & 19 & 3.9 & 7.9 & 80 & 5.8 & -57.7 & +15.2 \\
\hline IJ10 & 263 & 328 & $350 \mathrm{~m}$ & $\mathrm{HgCl}_{2}$ & 67 & 5.0 & 2.4 & 86 & 4.8 & -40.7 & +14.5 \\
\hline IJ11 & 380 & 274 & $350 \mathrm{~m}$ & $\mathrm{HgCl}_{2}$ & 41 & 4.7 & 5.1 & 76 & 12.3 & -48.8 & +15.7 \\
\hline IJ12 & 383 & 241 & $350 \mathrm{~m}$ & $\mathrm{HgCl}_{2}$ & 92 & 1.49 & 14.1 & 80 & 0.88 & -26.8 & +12.9 \\
\hline IJ13 & 358 & 262 & $50 \mathrm{~m}$ & $\mathrm{HgCl}_{2}$ & 19 & 2.6 & 8.1 & 75 & 11.9 & -55.3 & +6.0 \\
\hline IJ14 & 225 & 349 & $50 \mathrm{~m}$ & $\mathrm{HgCl}_{2}$ & 68 & 0.52 & 16.8 & 81 & 0.059 & +4.7 & +2.7 \\
\hline IJ15 & 420 & 252 & $50 \mathrm{~m}$ & $\mathrm{HgCl}_{2}$ & 42 & 4.0 & 3.6 & 83 & 7.5 & -45.0 & +4.7 \\
\hline IJ16 & 338 & 284 & $50 \mathrm{~m}$ & $\mathrm{HgCl}_{2}$ & 79 & 0.57 & 14.2 & 80 & 2.0 & -38.2 & +2.5 \\
\hline IJ17 & 341 & 229 & $350 \mathrm{~m}$ & $\mathrm{BKC}$ & 19 & 6.2 & 6.9 & 82 & 1.89 & -50.3 & +14.5 \\
\hline IJ18 & 264 & 281 & $350 \mathrm{~m}$ & BKC & 67 & 8.9 & 2.2 & 80 & 5.2 & -44.6 & +13.5 \\
\hline IJ19 & 388 & 253 & $350 \mathrm{~m}$ & BKC & 41 & 7.4 & 0.02 & 76 & 15.5 & -48.6 & +14.3 \\
\hline IJ20 & 333 & 302 & $350 \mathrm{~m}$ & BKC & 79 & 5.0 & 4.4 & 79 & 7.6 & -46.2 & +14.4 \\
\hline IJ 21 & 320 & 290 & $50 \mathrm{~m}$ & BKC & 19 & 4.7 & 1.82 & 85 & 5.5 & -46.2 & +3.7 \\
\hline IJ22 & 345 & 256 & $50 \mathrm{~m}$ & BKC & 68 & 3.7 & 8.2 & 84 & 2.3 & -26.7 & +2.8 \\
\hline IJ23 & 392 & 258 & $50 \mathrm{~m}$ & BKC & 42 & 4.4 & 3.2 & 80 & 10.2 & -42.7 & +4.3 \\
\hline IJ24 & 368 & 291 & $50 \mathrm{~m}$ & BKC & 79 & 2.2 & 4.1 & 80 & 10.2 & -41.8 & +2.2 \\
\hline IJ25 & 360 & 266 & $50 \mathrm{~m}$ & BKC & 79 & 2.6 & 3.0 & 79 & 13.4 & -43.5 & +3.2 \\
\hline IJ26 & 388 & 242 & $350 \mathrm{~m}$ & None & 5 & 2.3 & 14.2 & 79 & 3.6 & -55.4 & +14.5 \\
\hline IJ27 & 379 & 272 & $350 \mathrm{~m}$ & None & 5 & 3.0 & 11.6 & 78 & 6.1 & -53.8 & +14.8 \\
\hline IJ28 & 333 & 316 & $350 \mathrm{~m}$ & None & 5 & 2.1 & 12.7 & 80 & 3.5 & -55.5 & +15.1 \\
\hline
\end{tabular}

of $\mathrm{CH}_{4}$ and $\mathrm{CO}_{2}\left(\delta^{13} \mathrm{C}_{\mathrm{CO} 2}-\delta^{13} \mathrm{C}_{\mathrm{CH} 4}=\right.$ isotopic separation factor; [46]) in the Horonobe area decrease slightly $(<1 \%$ ) with increasing depth and temperature according to isotopic equilibrium values, with values at depths of $250 \mathrm{~m}$ and $350 \mathrm{~m}$ being similar to each other within the natural variation of $\sim 2 \%$ o $(1 \sigma)$ [28]. Therefore, $\delta^{13} \mathrm{C}_{\mathrm{CO} 2}$ and $\delta^{13} \mathrm{C}_{\mathrm{CH} 4}$ values of $250 \mathrm{~m}$ groundwater obtained by the EV method (Table 3 ) were used as reference values for the IsoJar ${ }^{\mathrm{TM}}$ samples with $350 \mathrm{~m}$ groundwater.

The $\delta^{13} \mathrm{C}_{\mathrm{CO} 2}$ values for IsoJar ${ }^{\mathrm{TM}}$ samples show two separate trends for $350 \mathrm{~m}$ and $50 \mathrm{~m}$ groundwater, with both showing a slight decrease over time, from $+15 \%$ at $5 \mathrm{~d}$ to $+13 \%$ at $92 \mathrm{~d}$ and from $+5 \%$ at $17 \mathrm{~d}$ to $-1 \%$ o to $+3 \%$ at $79 \mathrm{~d}$, respectively (Figure $4(\mathrm{a})$ ). The patterns are the same for both $\mathrm{BKC}$ and $\mathrm{HgCl}_{2}$ additives. The two trends suggest that the $\delta^{13} \mathrm{C}_{\mathrm{CO} 2}$ ratios represent dissolved gases from different depths. The concentration of $\mathrm{CO}_{2}$ in the groundwater, as $\mathrm{HCO}_{3}{ }^{-}$, is relatively high even when degassed at atmospheric pressure (30-50 mmol kg-1; [47]), compared with that of adsorbed $\mathrm{CO}_{2}$, so carbon isotopic values should be largely dependent on dissolved $\mathrm{CO}_{2}$. The $\delta^{13} \mathrm{C}_{\mathrm{CO} 2}$ values of samples with $50 \mathrm{~m}$ groundwater (dashed line in Figure 4(a)) are distinct from those of samples with $350 \mathrm{~m}$ groundwater, indicating that the former samples are strongly contaminated.

The $\delta^{13} \mathrm{C}_{\mathrm{CH} 4}$ values for IsoJar ${ }^{\mathrm{TM}}$ samples (Figure $4(\mathrm{~b})$ ) increase markedly with time regardless of additives and fluctuate by more than $30 \%$ after $80 \mathrm{~d}$; separate trends for different depths are not evident. The concentration of $\mathrm{CH}_{4}$ remaining in the groundwater at atmospheric pressure after sampling is relatively low $\left(\sim 3 \mathrm{mmol} \mathrm{kg}^{-1}\right.$; [47]), and $\delta^{13} \mathrm{C}_{\mathrm{CH} 4}$ values for the IsoJar ${ }^{\mathrm{TM}}$ samples mainly represent gases adsorbed on cores. Therefore, while the relatively large amounts of dissolved $\mathrm{CO}_{2}$ reduced the effects of isotopic fractionation on $\delta^{13} \mathrm{C}_{\mathrm{CO} 2}$ values, $\delta^{13} \mathrm{C}_{\mathrm{CH} 4}$ values were strongly affected.

The results of the effect of additives as described in Section 3.1.2 are shown and discussed in Section 5.2.

\section{Discussion}

5.1. Methane Oxidation. During methane oxidation, decreasing $\mathrm{CH}_{4}$ and increasing $\mathrm{CO}_{2}$ concentrations are associated 
TABLE 2: Information on IsoJar ${ }^{\mathrm{TM}}$ samples and analytical results of headspace gases for Section 3.1.2.

\begin{tabular}{|c|c|c|c|c|c|c|c|c|c|c|c|c|}
\hline $\begin{array}{l}\text { Sample } \\
\text { no. }\end{array}$ & $\begin{array}{l}\text { Amount } \\
\text { of core } \\
\text { sample (g) }\end{array}$ & $\begin{array}{c}\text { Amount of } \\
\text { water }(\mathrm{g})\end{array}$ & $\begin{array}{l}\text { Type of } \\
\text { additive }\end{array}$ & $\begin{array}{l}\text { Amount of } \\
\text { additive }(\mathrm{ml})\end{array}$ & $\begin{array}{c}\text { Concentration } \\
\text { of additives } \\
\text { (wt } \%)\end{array}$ & $\begin{array}{l}\text { Storage } \\
\text { period } \\
\text { (days) }\end{array}$ & $\begin{array}{l}\mathrm{CO}_{2} \\
(\%)\end{array}$ & $\begin{array}{l}\mathrm{O}_{2} \\
(\%)\end{array}$ & $\begin{array}{l}\mathrm{N}_{2} \\
(\%)\end{array}$ & $\begin{array}{l}\mathrm{CH}_{4} \\
(\%)\end{array}$ & $\begin{array}{c}\delta^{13} \mathrm{C}_{\mathrm{CH} 4} \\
(\% \text { VPDB) }\end{array}$ & $\begin{array}{c}\delta^{13} \mathrm{C}_{\mathrm{CO} 2} \\
(\% \text { VPDB) }\end{array}$ \\
\hline IJ29 & 311 & 310 & None & 0 & 0 & 27 & 12.8 & 1.0 & 86 & 0.039 & -48.3 & +14.2 \\
\hline IJ30 & 299 & 282 & None & 0 & 0 & 27 & 13.7 & 1.0 & 85 & 0.029 & -74.6 & +15.2 \\
\hline IJ31 & 284 & 324 & $\mathrm{BKC}$ & 1 & 0.03 & 27 & 12.5 & 1.0 & 86 & 0.036 & -74.2 & +14.0 \\
\hline IJ32 & 323 & 297 & BKC & 1 & 0.03 & 27 & 12.4 & 1.0 & 87 & 0.040 & -84.1 & +13.8 \\
\hline IJ33 & 332 & 312 & BKC & 3 & 0.10 & 27 & 11.6 & 4.2 & 84 & 0.053 & -88.5 & +13.9 \\
\hline IJ34 & 352 & 279 & BKC & 3 & 0.11 & 28 & 13.1 & 2.0 & 85 & 0.046 & -75.7 & +13.0 \\
\hline IJ35 & 368 & 290 & BKC & 6 & 0.20 & 28 & 10.2 & 4.1 & 86 & 0.067 & -58.1 & +12.9 \\
\hline IJ36 & 382 & 278 & BKC & 6 & 0.21 & 28 & 10.2 & 2.9 & 87 & 0.067 & -90.4 & +12.5 \\
\hline IJ37 & 309 & 299 & $\mathrm{BKC}$ & 10 & 0.32 & 28 & 12.8 & 7.3 & 80 & 0.054 & -56.2 & +14.8 \\
\hline IJ38 & 310 & 280 & BKC & 10 & 0.34 & 28 & 12.8 & 6.6 & 80 & 0.052 & -57.9 & +14.6 \\
\hline IJ39 & 340 & 285 & BKC & 20 & 0.66 & 29 & 10.9 & 6.2 & 83 & 0.068 & -54.5 & +13.6 \\
\hline IJ40 & 336 & 309 & $\mathrm{BKC}$ & 20 & 0.61 & 29 & 9.0 & 3.7 & 87 & 0.105 & -57.9 & +13.4 \\
\hline IJ41 & 272 & 319 & $\mathrm{HgCl}_{2}$ & 1 & 0.02 & 29 & 8.7 & 10.9 & 80 & 0.042 & -59.0 & +15.0 \\
\hline IJ42 & 323 & 296 & $\mathrm{HgCl}_{2}$ & 1 & 0.02 & 29 & 10.2 & 9.9 & 80 & 0.041 & -63.1 & +14.9 \\
\hline IJ43 & 348 & 284 & $\mathrm{HgCl}_{2}$ & 5 & 0.13 & 29 & 10.8 & 9.2 & 80 & 0.037 & -65.4 & +15.0 \\
\hline IJ44 & 319 & 314 & $\mathrm{HgCl}_{2}$ & 5 & 0.12 & 29 & 11.0 & 9.0 & 80 & 0.044 & -60.1 & +14.8 \\
\hline IJ45 & 293 & 322 & $\mathrm{HgCl}_{2}$ & 10 & 0.22 & 30 & 12.7 & 8.4 & 79 & 0.043 & -62.6 & +15.2 \\
\hline IJ46 & 362 & 293 & $\mathrm{HgCl}_{2}$ & 10 & 0.24 & 30 & 13.3 & 6.9 & 80 & 0.046 & -61.9 & +15.3 \\
\hline IJ47 & 285 & 308 & $\mathrm{HgCl}_{2}$ & 20 & 0.45 & 30 & 21 & 7.0 & 72 & 0.033 & -62.2 & +16.6 \\
\hline IJ48 & 362 & 295 & $\mathrm{HgCl}_{2}$ & 20 & 0.47 & 30 & 23 & 6.0 & 71 & 0.045 & -62.1 & +16.1 \\
\hline
\end{tabular}

TABLE 3: $\delta{ }^{13} \mathrm{C}_{\mathrm{CH} 4}, \delta^{13} \mathrm{C}_{\mathrm{CO} 2}$, methane, and TIC contents in EV samples.

\begin{tabular}{|c|c|c|c|c|c|c|}
\hline Sample no. & $\begin{array}{l}\text { Storage period } \\
\quad \text { (days) }\end{array}$ & $\begin{array}{l}\text { Sampling depth } \\
\text { of groundwater } \\
\text { (ground level -m) }\end{array}$ & $\begin{array}{c}{ }^{{ }^{13}} \mathrm{C}_{\mathrm{CH} 4} \\
(\% \text { VPDB })\end{array}$ & $\begin{array}{c}{ }^{{ }^{13} \mathrm{C}_{\mathrm{CO} 2}} \\
(\% \text { VPDB })\end{array}$ & $\begin{array}{c}\text { Concentration } \\
\text { of dissolved } \mathrm{CH}_{4} \\
\left(\mathrm{mmol} \mathrm{kg}^{-1}\right)\end{array}$ & $\begin{array}{l}\text { Concentration of total } \\
\text { inorganic carbon } \\
\text { (TIC) }\left(\mathrm{mmol} \mathrm{kg}^{-1}\right)\end{array}$ \\
\hline EV1 & 6 & 248.5 & -56.7 & +17.1 & - & - \\
\hline EV2 & 55 & 248.5 & -54.0 & +17.8 & 7.8 & - \\
\hline EV3 & 98 & 248.5 & -53.7 & +17.3 & 8.5 & - \\
\hline EV4 & 6 & 248.5 & -56.8 & +16.9 & 8.7 & 42 \\
\hline EV5 & 55 & 248.5 & -54.5 & +16.2 & 6.7 & 37 \\
\hline EV6 & 98 & 248.5 & -52.7 & +16.7 & 6.7 & 35 \\
\hline
\end{tabular}

with carbon isotopic fractionation, resulting in enrichment of ${ }^{13} \mathrm{C}$ in unreacted $\mathrm{CH}_{4}$ and depletion in $\mathrm{CO}_{2}$ produced. However, there is no clear relationship between headspace gas concentrations and storage period, possibly because of the variability of adsorbed gas levels in natural samples. An apparent carbon isotopic fractionation factor, $\alpha$, defined as $\alpha=\left(\delta^{13} \mathrm{C}_{\mathrm{CO} 2}+1000\right) /\left(\delta^{13} \mathrm{C}_{\mathrm{CH} 4}+1000\right)$, was calculated using the $\delta^{13} \mathrm{C}_{\mathrm{CO} 2}$ and $\delta^{13} \mathrm{C}_{\mathrm{CH} 4}$ values in Table 1 (Figure 5). Initial values of $\alpha$ in the Horonobe samples, calculated using the results of the EV method, were around 1.06-1.08, in good agreement with those determined by Miyakawa et al. [28]. The values of $\alpha$ for the IsoJar ${ }^{\mathrm{TM}}$ samples decreased from $\sim 1.07$ to 1.04 with increasing storage time (Figure 5). An earlier study reported a similar trend, where microbial methane oxidation in marine sediments gave an $\alpha$ value of $\sim 1.08$ in the methanogenesis zone, decreasing to $\sim 1.02$ in the methane oxidation zone [48].
A bivariate plot of $\delta^{13} \mathrm{C}_{\mathrm{CH} 4}$ vs. $\delta^{13} \mathrm{C}_{\mathrm{CO} 2}$ (Figure 6) indicates two trends for the IsoJar ${ }^{\mathrm{TM}}$ samples (Figure 6(b)), as in Figure 4(a). Thus, data plotted in Figures 4-6 indicate that $\delta^{13} \mathrm{C}_{\mathrm{CH} 4}$ values in samples stored for more than one week were affected by $\mathrm{CH}_{4}$ oxidation to $\mathrm{CO}_{2} \cdot \delta^{13} \mathrm{C}_{\mathrm{CH}}$ and $\delta^{13} \mathrm{C}_{\mathrm{CO} 2}$ values reported by Funaki et al. [14] are plotted between the two trends (Figure 6(b)). It seems, therefore, that the variations can be explained by the mixing of the two trends, indicating effects of both methane oxidation and contamination of $50 \mathrm{~m}$ groundwater in the IsoJar ${ }^{\mathrm{TM}}$ container after sampling.

5.2. Effect of Additives. Significant isotopic fractionation occurred in the IsoJar ${ }^{\mathrm{TM}}$ samples, strongly affecting $\delta^{13} \mathrm{C}_{\mathrm{CH} 4}$ values despite the addition of $\mathrm{BKC}$ or $\mathrm{HgCl}_{2}$ (Figure 4), suggesting that the amounts of additives used were insufficient to suppress microbial activity. Results of effect of additives as 


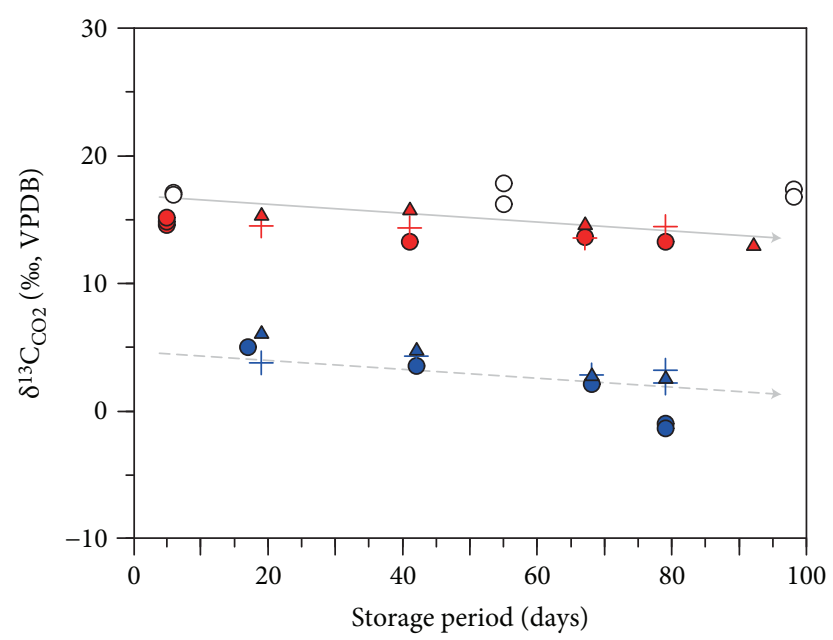

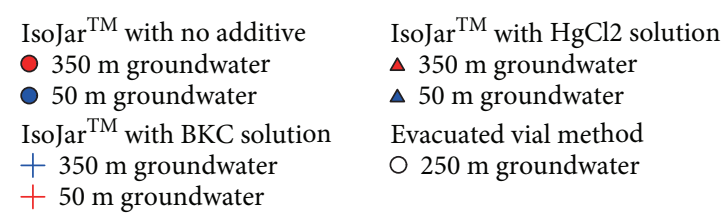

(a)

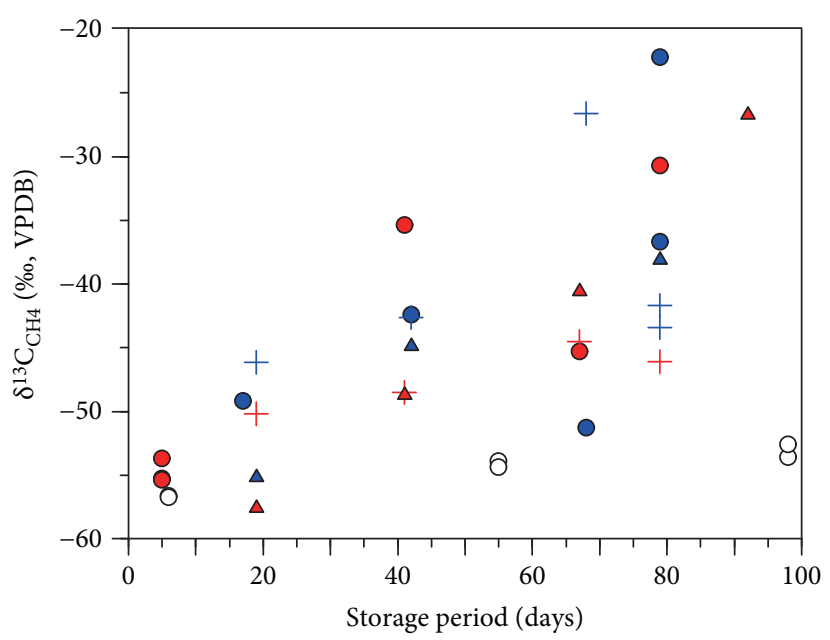

IsoJar ${ }^{\mathrm{TM}}$ with no additive
$350 \mathrm{~m}$ groundwater
$50 \mathrm{~m}$ groundwater
IsoJar ${ }^{\mathrm{TM}}$ with $\mathrm{BKC}$ solution
$+350 \mathrm{~m}$ groundwater
$+50 \mathrm{~m}$ groundwater

IsoJar ${ }^{\mathrm{TM}}$ with $\mathrm{HgCl} 2$ solution

$\Delta 350 \mathrm{~m}$ groundwater

$\Delta 50 \mathrm{~m}$ groundwater

Evacuated vial method

○ $250 \mathrm{~m}$ groundwater

(b)

FIGURE 4: Temporal variations in (a) $\delta^{13} \mathrm{C}_{\mathrm{CO} 2}$ and (b) $\delta^{13} \mathrm{C}_{\mathrm{CH} 4}$ after sampling. Solid arrow indicates the trend for samples with $350 \mathrm{~m}$ groundwater; dashed arrow indicates the trend for samples with $50 \mathrm{~m}$ groundwater.

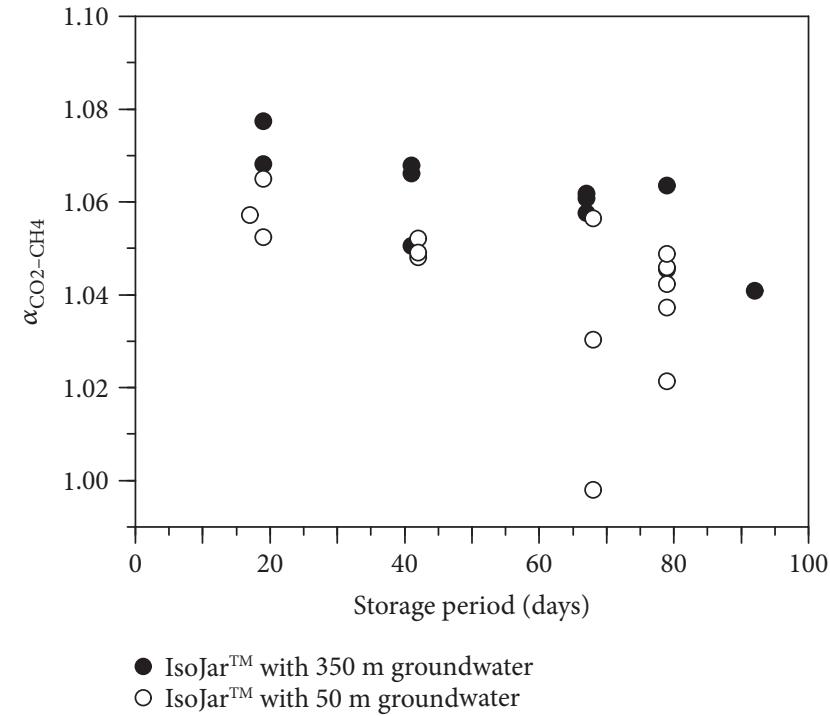

FIGURE 5: Temporal variations in the apparent carbon isotopic fractionation factor, $\alpha$, between $\mathrm{CO}_{2}$ and $\mathrm{CH}_{4}$.

described in Section 3.1.2 are listed in Table 2 and shown in Figure 7 . With $<10 \mathrm{ml}$ BKC solution or $<0.3 \%$ BKC concentration, $\delta^{13} \mathrm{C}_{\mathrm{CH} 4}$ values fluctuated significantly, and isotopic compositions became lighter. This is opposite to the effect of microbial carbonate reduction and may be due to low $\mathrm{CH}_{4}$ concentrations (Table 2) resulting from storage of the cores for about six months in a vacuum container (to avoid oxidation by the air and drying), possibly with significant removal of adsorbed gases. An instrumental mass bias of carbon isotope ratio was reported in a very low concentration of hydrocarbons with respect to mass spectrometry [49]. In this study, all the data of $\mathrm{CH}_{4}$ concentrations were above the lower limit of determination of $0.01 \%$ (Table 2) indicating that large fluctuations of $\delta^{13} \mathrm{C}_{\mathrm{CH} 4}$ values (Figure 7) are not due to instrumental mass bias. The mechanism of any reaction opposing fractionation is not clear. In a low $\mathrm{CH}_{4}$ concentration, the carbon isotope ratio may be easily disturbed by complex microbial metabolism (e.g., methane oxidation and carbonate reduction). With $>10 \mathrm{ml}$ BKC solution or $>0.3 \%$ BKC concentration, the $\delta^{13} \mathrm{C}_{\mathrm{CH} 4}$ values were relatively constant at about $-56 \%$ (Figure 7 ), which is in good agreement with the values for EV samples.

Although the $\delta^{13} \mathrm{C}_{\mathrm{CH} 4}$ values for IsoJar ${ }^{\mathrm{TM}}$ samples with $\mathrm{HgCl}_{2}$ solution are relatively constant (Figure 7), they are consistently 5\%o-6\%o lower than those with BKC solution. Concentrations of $\mathrm{CO}_{2}$ in the headspace of samples IJ47 and IJ48, to which $20 \mathrm{ml} \mathrm{HgCl}_{2}$ solution was added, are considerably higher than those in the other samples (Table 2). A possible cause of the decrease in $\delta^{13} \mathrm{C}_{\mathrm{CH} 4}$ values may be isotopic fractionation associated with mercuric reactions with methane, which generate $\mathrm{HCl}$ and lead to $\mathrm{CO}_{2}$ outgassing. Although this mechanism is not clear, considerable care should be required using $\mathrm{HgCl}_{2}$ as a microbicide with respect to carbon isotope fractionation.

\section{Conclusions}

This study investigated the possible causes of carbon isotopic variations (in $\delta^{13} \mathrm{C}_{\mathrm{CH} 4}$ and $\delta^{13} \mathrm{C}_{\mathrm{CO} 2}$ values) in borehole drillings to $500 \mathrm{~m}$ depth, as reported by Funaki et al. [14]. The results have led to improvements in the IsoJar ${ }^{\mathrm{TM}}$ method for the determination of carbon isotopic ratios in $\mathrm{CH}_{4}$ and 


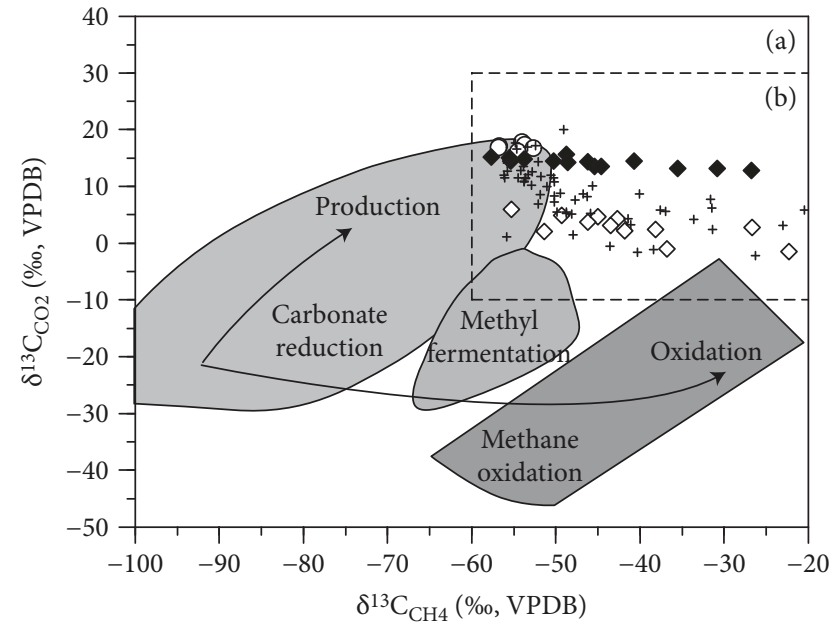

(a)

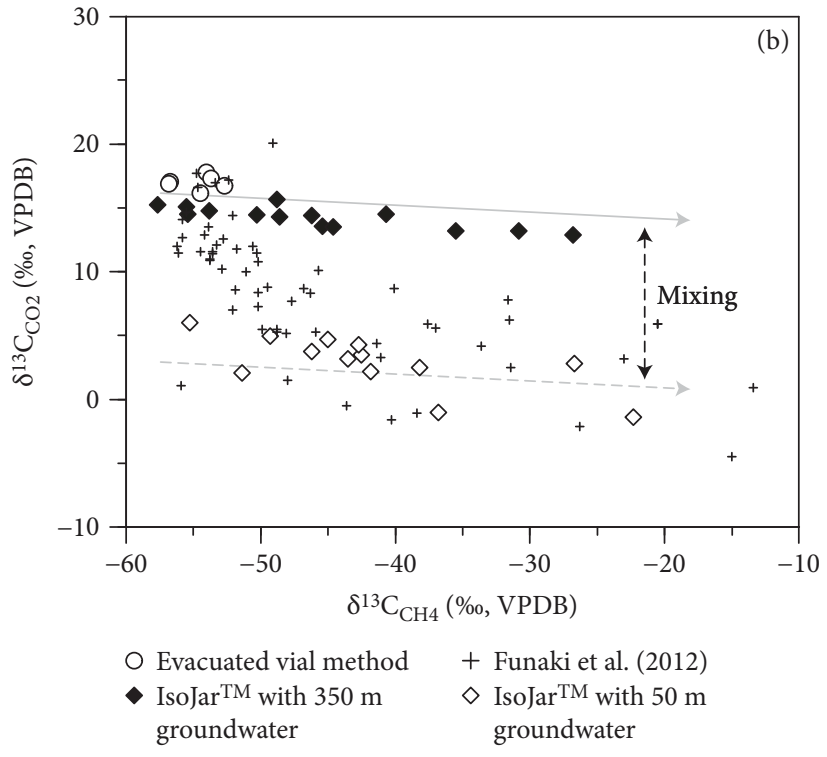

(b)

Figure 6: Plot of $\delta^{13} \mathrm{C}_{\mathrm{CH} 4}$ vs. $\delta^{13} \mathrm{C}_{\mathrm{CO} 2}$ in coexisting gases. (a) Grey areas show fields relating to different gas sources and isotopic shifts resulting from production and oxidation (adapted from [50]). The area indicated by the dashed rectangle is enlarged in (b). (b) Solid arrow indicates a methane oxidation trend for samples with $350 \mathrm{~m}$ groundwater; dashed arrow indicates the trend for samples with $50 \mathrm{~m}$ groundwater.

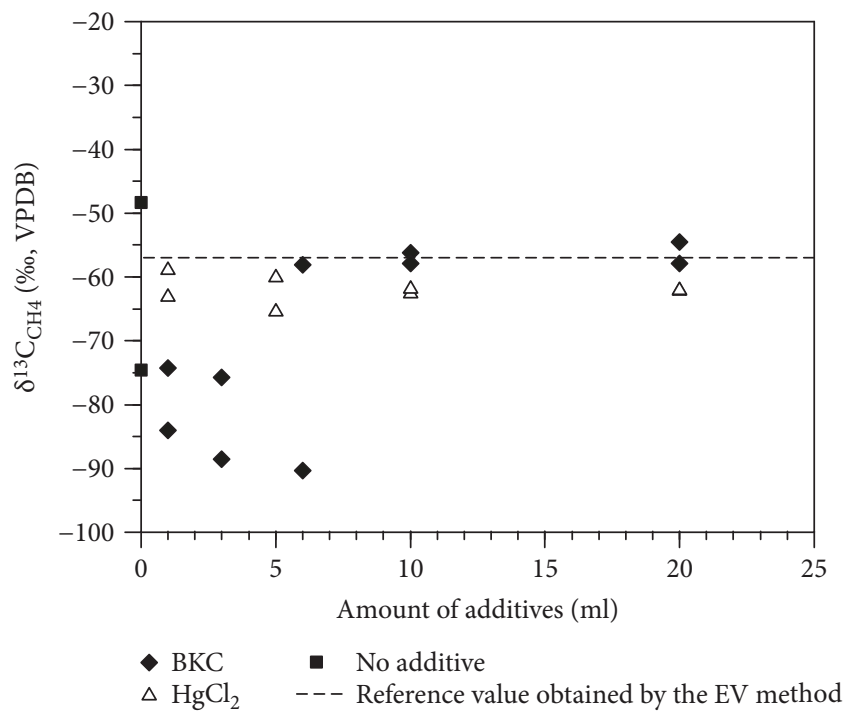

(a)

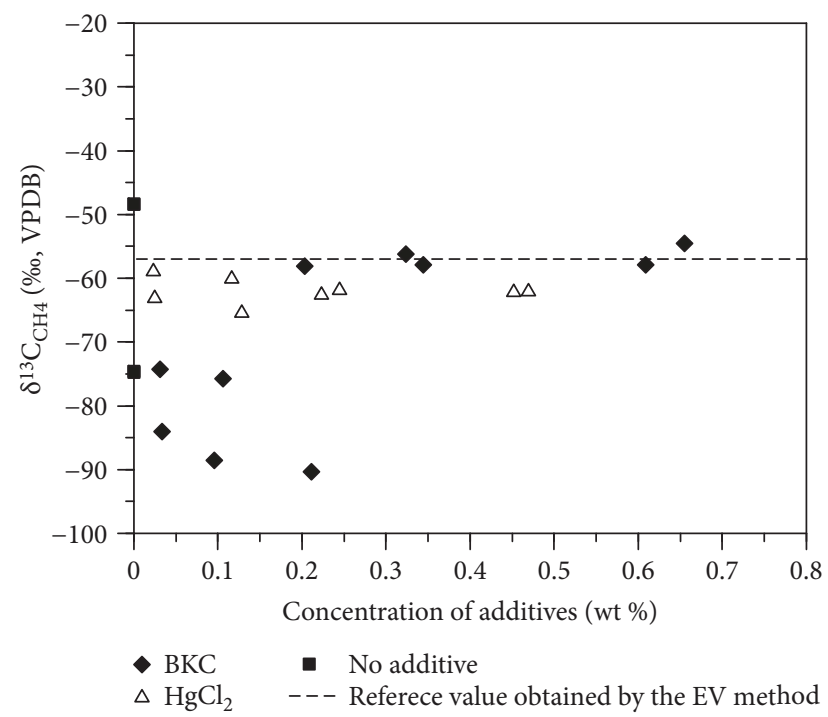

(b)

Figure 7: Plot of $\delta^{13} \mathrm{C}_{\mathrm{CH} 4}$ values vs. (a) amount of microbial suppressant used and (b) concentration of additives.

$\mathrm{CO}_{2}$ adsorbed on bore cores. It was found that with air in the IsoJar ${ }^{\mathrm{TM}}$ headspace, microbes oxidize $\mathrm{CH}_{4}$ to $\mathrm{CO}_{2}$ during storage, accompanied by isotopic fractionation, especially for samples from depths of $<1000 \mathrm{~m}$ where microbes are more active. Isotopic fractionation resulted in $\delta^{13} \mathrm{C}_{\mathrm{CH} 4}$ and $\delta^{13} \mathrm{C}_{\mathrm{CO} 2}$ values reaching $>30 \%$ and $>2 \%$ after $80 \mathrm{~d}$ storage, respectively, while samples analyzed within a week of sampling showed no such effect. The significant isotopic fractionation in $\mathrm{CH}_{4}$ was due to its low concentration in the sampling container, while the weaker fractionation in $\mathrm{CO}_{2}$ was due to its relatively high concentration. The conventional amount of BKC additive ( $\sim 0.5 \mathrm{ml}$ of $10 \%$ solution) was insufficient to suppress microbial activity at least when using in situ groundwater as filling water. The large variations in isotopic compositions reported by Funaki et al. [14] thus appear to have been caused by microbial methane oxidation in the IsoJar $^{\mathrm{TM}}$ containers after sampling and contamination with groundwater from different depths. Important technique improvements are summarized as follows: (1) if long-term sample storage is necessary, $>10 \mathrm{ml}$ of $10 \% \mathrm{BKC}$ solution 
should be used or $>0.3 \%$ BKC concentration is required; (2) analysis within a week of sampling is strongly recommended; and (3) for $\mathrm{CO}_{2}$ analysis, groundwater from different depths should not be used.

\section{Data Availability}

The all data used to support the findings of this study are included within the article and Supplementary information file.

\section{Conflicts of Interest}

The authors declare that there is no conflict of interest regarding the publication of this paper.

\section{Acknowledgments}

The authors are grateful to Hironori Funaki (JAEA) and Taiki Ishikawa (Mitsubishi Materials Techno (MMT)) for providing helpful information regarding sampling methods. Amane Waseda (JAPEX) provided valuable comments that greatly improved the manuscript. The authors would also like to thank Yusuke Kitagawa (MMT) and Eiichi Ishii (JAEA) for the help with sampling. Hiroshi Sasamoto (JAEA) and Aaron Stallard (Stallard Scientific Editing) are gratefully acknowledged for improving the manuscript.

\section{Supplementary Materials}

Sampling date, analysis date, sampling depth of cores, and carbon isotope ratios of $\mathrm{CH}_{4}$ and $\mathrm{CO}_{2}$ of headspace gases in IsoJar ${ }^{\mathrm{TM}}$ samples of Funaki et al. [14] (Tables S1a and S1b). Sampling date, analysis date, sampling depth of cores, and chemical compositions of headspace gases in IsoJar ${ }^{\mathrm{TM}}$ samples and EV samples of this study (Tables S2, S3, and S4). (Supplementary Materials)

\section{References}

[1] J. Aali, H. Rahimpour-Bonab, and M. R. Kamali, "Geochemistry and origin of the world's largest gas field from Persian Gulf, Iran," Journal of Petroleum Science and Engineering, vol. 50, no. 3-4, pp. 161-175, 2006.

[2] S. Kato, A. Waseda, H. Nishita, and H. Iwano, "Geochemistry of crude oils and gases from mud volcanoes and their vicinities in the Higashi-Kubiki area, Niigata Prefecture," Chigaku Zasshi (Jounal of Geography), vol. 118, no. 3, pp. 455-471, 2009.

[3] A. Prinzhofer and É. Pernaton, "Isotopically light methane in natural gas: bacterial imprint or diffusive fractionation?," Chemical Geology, vol. 142, no. 3-4, pp. 193-200, 1997.

[4] M. Schoell, "Isotope techniques for tracing migration of gases in sedimentary basins," Journal of the Geological Society, vol. 140, no. 3, pp. 415-422, 1983.

[5] L. R. Snowdon, "Natural gas composition in a geological environment and the implications for the processes of generation and preservation," Organic Geochemistry, vol. 32, no. 7, pp. 913-931, 2001.

[6] G. Bordeleau, C. Rivard, D. Lavoie et al., "Identifying the source of methane in groundwater in a 'virgin' area with regards to shale gas exploitation: a multi-isotope approach,"
Procedia Earth and Planetary Science, vol. 13, pp. 219-222, 2015.

[7] D. J. Miller, J. M. Ketzer, A. R. Viana et al., "Natural gas hydrates in the Rio Grande Cone (Brazil): a new province in the western South Atlantic," Marine and Petroleum Geology, vol. 67, pp. 187-196, 2015.

[8] J. M. Hunt, Petroleum Geochemistry and Geology, W. H. Freeman and Company, New York, NY, USA, 2nd edition, 1995.

[9] I. D. Clark, D. Ilin, R. E. Jackson et al., "Paleozoic-aged microbial methane in an Ordovician shale and carbonate aquiclude of the Michigan Basin, southwestern Ontario," Organic Geochemistry, vol. 83-84, pp. 118-126, 2015.

[10] C. R. Clarkson, S. M. Ghaderi, M. S. Kanfar et al., "Estimation of fracture height growth in layered tight/shale gas reservoirs using flowback gas rates and compositions-part II: field application in a liquid-rich tight reservoir," Journal of Natural Gas Science and Engineering, vol. 36, pp. 1031-1049, 2016.

[11] D. Lavoie, N. Pinet, G. Bordeleau et al., "The Upper Ordovician black shales of southern Quebec (Canada) and their significance for naturally occurring hydrocarbons in shallow groundwater," International Journal of Coal Geology, vol. 158, pp. 44-64, 2016.

[12] M. Schoell, "Recent advances in petroleum isotope geochemistry," Organic Geochemistry, vol. 6, pp. 645-663, 1984.

[13] A. Waseda and T. Uchida, "Origin and migration of methane in gas hydrate-bearing sediments in the Nankai Trough," The Geochemical Society Special Publications, vol. 9, pp. 377-387, 2004.

[14] H. Funaki, K. Ishiyama, A. Waseda, S. Kato, and K. Watanabe, "Molecular and carbon isotope compositions of hydrocarbon gas in Neogene sedimentary rocks in Horonobe area, northern Hokkaido, Japan," Journal of Geography, vol. 121, no. 6, pp. 929-945, 2012.

[15] Japan National Oil Corporation (JNOC), Report on the MITI Higashi-Kubiki Drilling. Japan Oil, Gas Metals National Corporation, 1991, (in Japanese).

[16] Japan National Oil Corporation (JNOC), Report on the MITI Mishima Drilling. Japan Oil, Gas Metals National Corporation, 1993, (in Japanese).

[17] Japan National Oil Corporation (JNOC), Report on the MITI Tempoku Drilling. Japan Oil, Gas Metals National Corporation, 1995, (in Japanese).

[18] A. Waseda, H. Iwano, and N. Takeda, "Geochemical study on origin and maturity of natural gases," Journal of the Japanese Association for Petroleum Technology, vol. 67, no. 1, pp. 315, 2002.

[19] B. J. Katz, "Microbial processes and natural gas accumulations," The Open Geology Journal, vol. 5, no. 1, pp. 75-83, 2011.

[20] S. S. Belyaev, R. Wolkin, W. R. Kenealy, M. J. Deniro, S. Epstein, and J. G. Zeikus, "Methanogenic bacteria from the Bondyuzhskoe oil field: general characterization and analysis of stable-carbon isotopic fractionation," Applied and Environmental Microbiology, vol. 45, no. 2, pp. 691-697, 1983.

[21] P. J. Waldron, S. T. Petsch, A. M. Martini, and K. Nüsslein, "Salinity constraints on subsurface archaeal diversity and methanogenesis in sedimentary rock rich in organic matter," Applied and Environmental Microbiology, vol. 73, no. 13, pp. 4171-4179, 2007.

[22] A. Visser, Y. Gao, and G. Lettinga, "Effects of $\mathrm{pH}$ on methanogenesis and sulphate reduction in thermophilic $\left(55^{\circ} \mathrm{C}\right) \mathrm{UASB}$ 
reactors," Bioresource Technology, vol. 44, no. 2, pp. 113-121, 1993.

[23] F. H. Chapelle and D. R. Lovley, "Rates of microbial metabolism in deep coastal plain aquifers," Applied and Environmental Microbiology, vol. 56, no. 6, pp. 1865-1874, 1990.

[24] N. Kaneko, "Methanogenic archaea," Journal of the Japanese Association for Petroleum Technology, vol. 68, no. 5, pp. 450457, 2003.

[25] D. D. Rice, "Controls, habitat, and resource potential of ancient bacterial gas," in Bacterial Gas, R. Vially, Ed., pp. 91118, Éditions Technip, 1992.

[26] H. Sakagami, N. Takahashi, A. Hachikubo et al., "Molecular and isotopic composition of hydrate-bound and dissolved gases in the southern basin of Lake Baikal, based on an improved headspace gas method," Geo-Marine Letters, vol. 32, no. 5-6, pp. 465-472, 2012.

[27] A. Hachikubo, K. Yanagawa, H. Tomaru, and R. Matsumoto, "Dissolved gas analysis of pore water in subsurface sediments retrieved at eastern margin of Japan Sea (MD179 gas hydrates cruise)," Journal of the Japanese Association for Petroleum Technology, vol. 77, no. 4, pp. 268-273, 2012.

[28] K. Miyakawa, E. Ishii, A. Hirota, D. D. Komatsu, K. Ikeya, and U. Tsunogai, "The role of low-temperature organic matter diagenesis in carbonate precipitation within a marine deposit," Applied Geochemistry, vol. 76, pp. 218-231, 2017.

[29] Y. Amano, I. Nanjo, H. Murakami et al., "Validation of surface-based hydrochemical investigation and the impact of underground facility construction at Horonobe URL," Journal of Groundwater Hydrology, vol. 54, no. 4, pp. 207-228, 2012.

[30] T. Iwatsuki, E. Ishii, and T. Niizato, "Scenario development of long-term evolution for deep hydrochemical conditions in Horonobe area, Hokkaido, Japan," Chigaku Zasshi (Jounal of Geography), vol. 118, no. 4, pp. 700-716, 2009.

[31] K. Miyakawa, T. Mezawa, A. Mochizuki, and H. Sasamoto, "Data of groundwater chemistry obtained in the Horonobe underground research laboratory project," JAEA-Data/Code 2017-012, Japan Atomic Energy Agency, 2017, (in Japanese with English abstract).

[32] T. Sasaki, T. Koukami, T. Kobayashi et al., "Determination of dissolved natural thorium and uranium in Horonobe and Mizunami Underground Research Laboratory groundwater and its thermodynamic analysis," Journal of Nuclear Science and Technology, vol. 54, pp. 373-381, 2017.

[33] Y. S. Togo, Y. Takahashi, Y. Amano et al., "Age and speciation of iodine in groundwater and mudstones of the Horonobe area, Hokkaido, Japan: implications for the origin and migration of iodine during basin evolution," Geochimica et Cosmochimica Acta, vol. 191, pp. 165-186, 2016.

[34] K. Miyakawa, S. Tamamura, K. Nakata, and T. Hasegawa, "Gas composition related to the Horonobe Underground Research Laboratory project," JAEA-Data/Code 2016-021, Japan Atomic Energy Agency, 2017, (in Japanese with English abstract).

[35] S. Tamamura, M. Akatsuka, R. Ikawa et al., "Origin of methane dissolved in formation waters in the Koetoi Formation through to the alluvium in northwestern part of Hokkaido, Japan," Chikyukagaku, vol. 48, pp. 39-50, 2014.

[36] E. Ishii, H. Sanada, T. Iwatsuki, Y. Sugita, and H. Kurikami, "Mechanical strength of the transition zone at the boundary between opal-A and opal-CT zones in siliceous rocks," Engineering Geology, vol. 122, no. 3-4, pp. 215-221, 2011.
[37] T. Mezawa, K. Miyakawa, H. Sasamoto, and K. Soga, "Development and improvement of geochemical monitoring system for groundwater installed in the $350 \mathrm{~m}$ gallery of the Horonobe Underground Research Laboratory," JAEA-Technology 2016003, Japan Atomic Energy Agency, 2016, (in Japanese with English abstract).

[38] K. Kai and K. Maekawa, "Oxygen and hydrogen isotopic ratios and $\mathrm{Cl}^{-}$concentration of saline water in the Neogene siliceous sediments of Horonobe, Hokkaido, Japan," Journal of the Japanese Association for Petroleum Technology, vol. 74, no. 1, pp. 96-106, 2009.

[39] A. Ueda, K. Nagao, T. Shibata, and T. Suzuki, "Stable and noble gas isotopic study of thermal and groundwaters in northwestern Hokkaido, Japan and the occurrence of geopressured fluids," Geochemical Journal, vol. 44, no. 6, pp. 545-560, 2010.

[40] A. W. Hernsdorf, Y. Amano, K. Miyakawa et al., "Potential for microbial $\mathrm{H}_{2}$ and metal transformations associated with novel bacteria and archaea in deep terrestrial subsurface sediments," ISME Journal, vol. 11, no. 8, pp. 1915-1929, 2017.

[41] K. Kato, K. Nagaosa, H. Kimura et al., "Unique distribution of deep groundwater bacteria constrained by geological setting," Environmental Microbiology Reports, vol. 1, no. 6, pp. 569574, 2009.

[42] S. Shimizu, M. Akiyama, Y. Ishijima, K. Hama, T. Kunimaru, and T. Naganuma, "Molecular characterization of microbial communities in fault-bordered aquifers in the Miocene formation of northernmost Japan," Geobiology, vol. 4, no. 3, pp. $203-$ 213, 2006.

[43] A. Waseda and H. Iwano, "Characterization of natural gases in Japan based on molecular and carbon isotope compositions," Geofluids, vol. 8, no. 4, 292 pages, 2008.

[44] W. G. Mook, J. C. Bommerson, and W. H. Staverman, "Carbon isotope fractionation between dissolved bicarbonate and gaseous carbon dioxide," Earth and Planetary Science Letters, vol. 22, no. 2, pp. 169-176, 1974.

[45] T. Miyoshi, T. Iwatsuki, and T. Naganuma, "Phylogenetic characterization of $16 \mathrm{~S}$ rRNA gene clones from deepgroundwater microorganisms that pass through 0.2-micrometer-pore-size filters," Applied and Environmental Microbiology, vol. 71, no. 2, pp. 1084-1088, 2005.

[46] M. Frye, Preliminary Evaluation of In-place Gas Hydrate Resources: Gulf of Mexico Outer Continental Shelf, OCS Report MMS 2008-004, 2008.

[47] S. Tamamura, K. Miyakawa, N. Aramaki, T. Igarashi, and K. Kaneko, "A proposed method to estimate in situ dissolved gas concentrations in gas-saturated groundwater," Groundwater, vol. 56, no. 1, pp. 118-130, 2018.

[48] M. J. Whiticar and E. Faber, "Methane oxidation in sediment and water column environments-isotope evidence," Organic Geochemistry, vol. 10, no. 4-6, pp. 759-768, 1986.

[49] N. Kaneko, T. Maekawa, S. Igari, and S. Sakata, "Carbon isotope analysis of natural gas components using a gas chromatograph/combustion/mass spectrometer (GC/C/MS)," Bulletin of the Geological Survey of Japan, vol. 50, pp. 383-393, 1999.

[50] M. J. Whiticar, "Carbon and hydrogen isotope systematics of bacterial formation and oxidation of methane," Chemical Geology, vol. 161, no. 1-3, pp. 291-314, 1999. 
[51] E. Ishii, K. Yasue, H. Ohira, A. Furusawa, T. Hasegawa, and M. Nakagawa, "Inception of anticline growth near the Omagari Fault, northern Hokkaido, Japan," Journal of Geological Society of Japan, vol. 114, no. 6, pp. 286-299, 2008.

[52] D. Wei and T. Seno, "Determination of the Amurian Plate motion," in Mantle Dynamics and Plate Interactions in East Asia, Geodynamics Series 27, M. Flower, S. L. Chung, C. H. Lo, and T. Y. Lee, Eds., pp. 337-346, American Geophysical Union, Washington, DC, USA, 1998. 

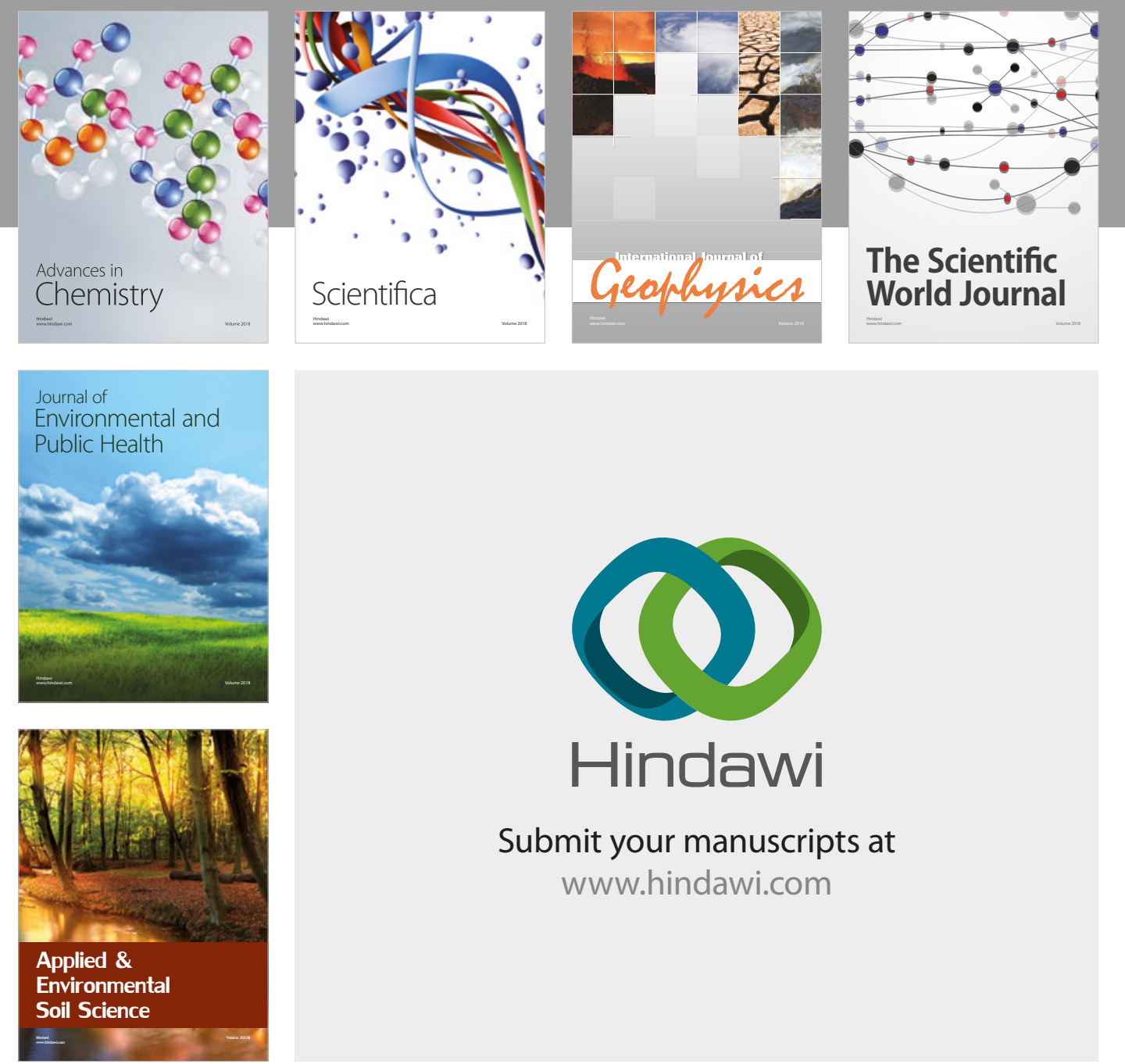

The Scientific

\section{World Journal}
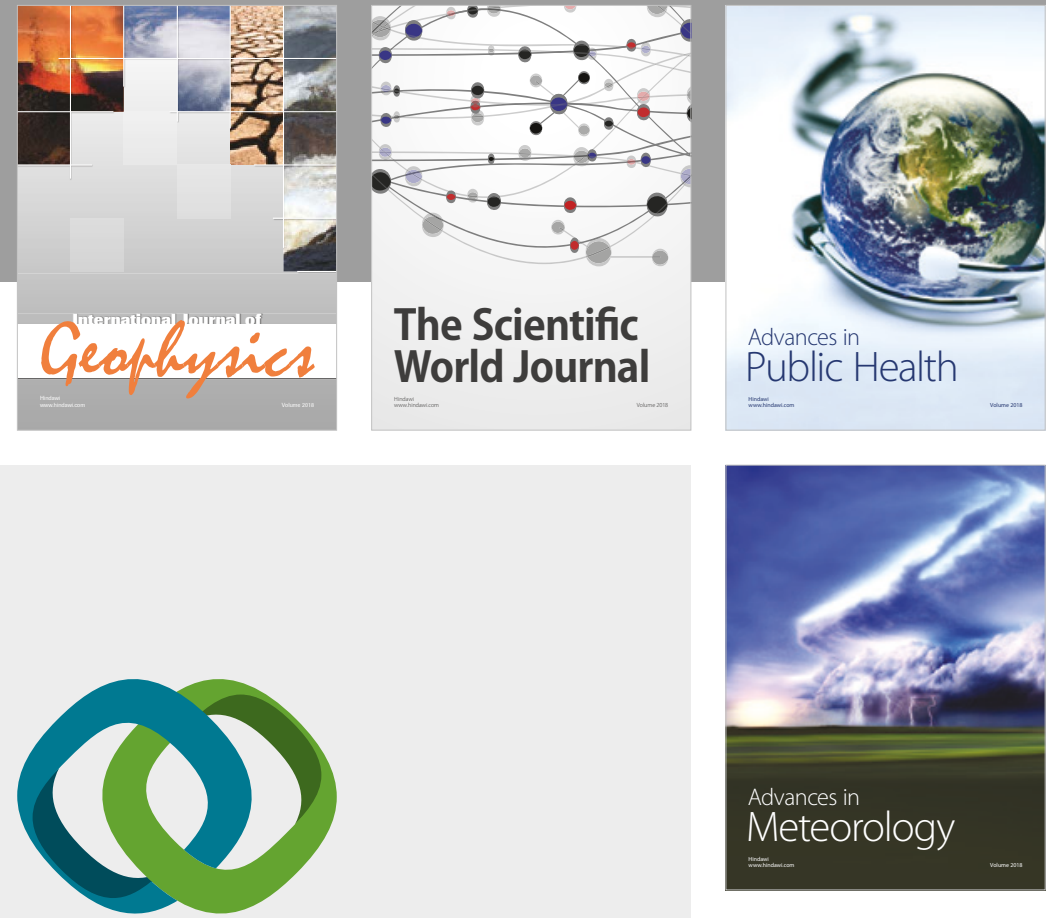

Advan

Public Health

\section{Hindawi}

Submit your manuscripts at

www.hindawi.com
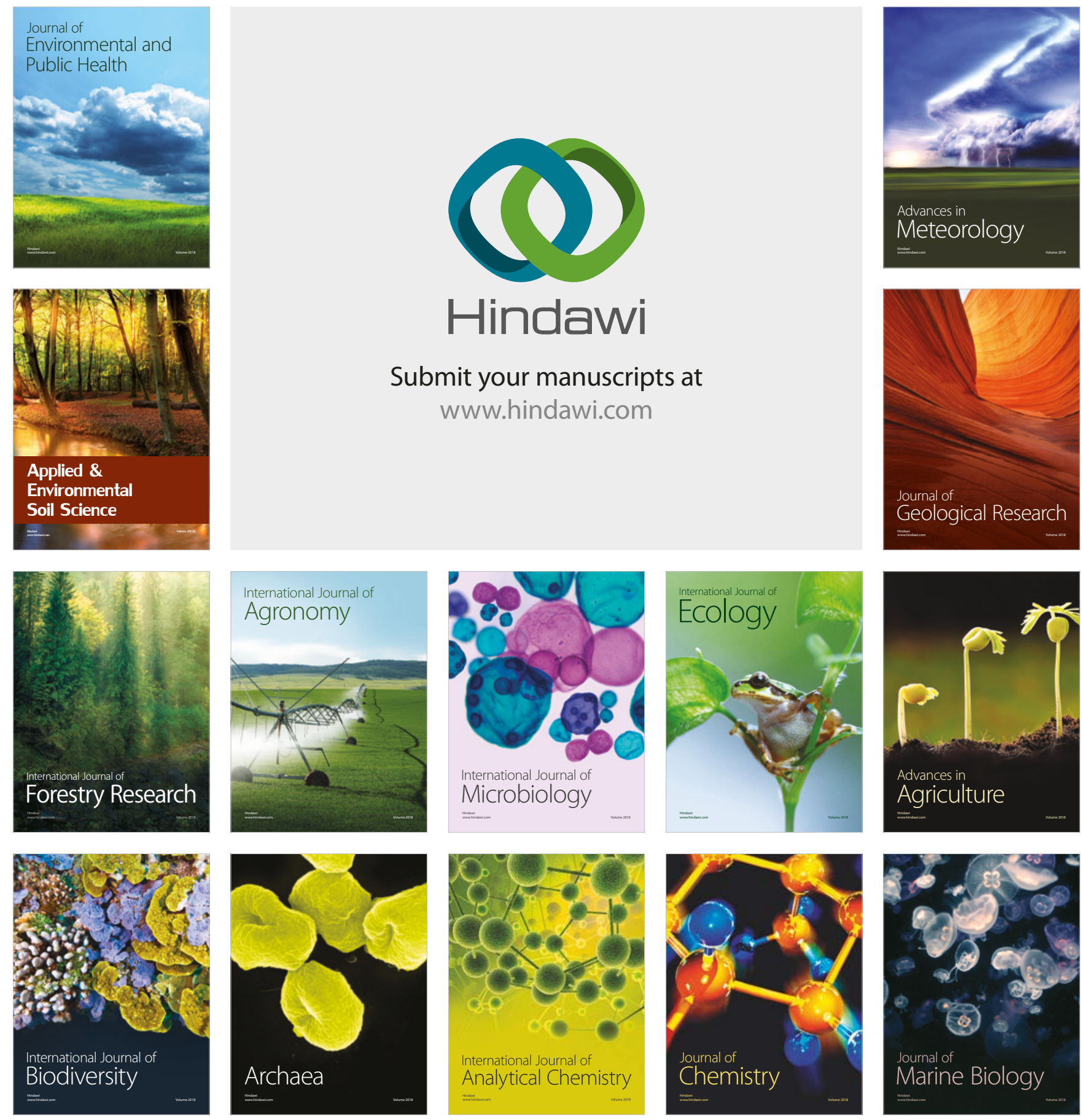